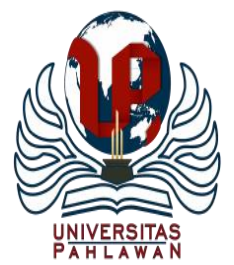

Edukatif : Jurnal Ilmu Pendidikan Volume 3 Nomor 4 Tahun 2021 Halm 1271 - 1282

EDUKATIF: JURNAL ILMU PENDIDIKAN

Research \& Learning in Education

https:/ledukatif.org/index.php/edukatif/index

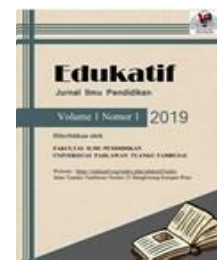

\title{
Pengembangan Video Animasi Sebagai Upaya Peningkatan Minat Belajar Peserta Didik Materi Perpajakan di Sekolah Menengah Atas
}

\author{
Febby Febriantika Noer Fisabilillah ${ }^{1 凶}$, Norida Canda Sakti ${ }^{2}$ \\ Universitas Negeri Surabaya, Indonesia ${ }^{1,2}$ \\ E-mail : febbyfebrie80@gmail.com ${ }^{1}$, noridacanda@unesa.ac.id ${ }^{2}$
}

\begin{abstract}
Abstrak
Penelitian ini dilakukan berdasarkan permasalahan belajar daring karena rendahnya perasaan senang, keterlibatan, ketertarikan, dan perhatian peserta didik, sehingga diperlukan media pembelajaran untuk menarik minat belajar peserta didik. Penelitian ini dilakukan bertujuan untuk mengetahui kelayakan, efektifitas, kepraktisan, sekaligus respon peserta didik dan pengembangan media pembelajaran video animasi. Jenis metode yang digunakan dalam penelitian ini adalah Research and Development (R\&D) dengan menerapkan 4 tahapan (4D). Hasil data penelitian yang diperoleh dari validasi ahli menunjukkan perolehan validasi kelayakan 97\% untuk media dan 89,5\% untuk materi, keefektifan 92\%, dan kepraktisan 94\% dengan kategori sangat layak. Respon peserta didik dengan adanya penerapan media pembelajaran video animasi memperoleh presentase 87,9\% dengan kategori sangat layak. Sehingga dapat disimpulkan bahwa media video animasi dinyatakan layak, efektif, dan praktis untuk dijadikan media pembelajaran disekolah terutama saat daring. Selain itu, pengembangan media pembelajaran video animasi efektif digunakan yang dapat dianalisis dari presentase respon peserta didik sebesar $87,9 \%$ yang berarti sangat baik untuk dijadikan sebagai upaya peningkatan minat belajar peserta didik.
\end{abstract}

Kata Kunci: Pengembangan, Media, Pembelajaran, Pendidikan, Ekonomi.

\begin{abstract}
This research was conducted based on online learning problems because of the low feeling of pleasure, involvement, interest, and attention of students, so that learning media is needed to attract students' interest in learning. This research was conducted to determine the feasibility, effectiveness, practicality, as well as student responses, and the development of animated video learning media. The type of method used in this research is Research and Development $(R \& D)$ by applying 4 stages $(4 D)$. The results of the research data obtained from expert validation showed the acquisition of feasibility validation of $97 \%$ for media and $89.5 \%$ for material, 92\% effectiveness, and 94\% practicality with very feasible categories. The response of students with the application of animated video learning media obtained a percentage of $87.9 \%$ with a very feasible category. So it can be concluded that animated video media is declared feasible, effective, and practical to be used as learning media in schools, especially when online. In addition, the development of effective animated video learning media is used which can be analyzed from the percentage of student responses of $87.9 \%$ which means it is very good to be used as an effort to increase students' interest in learning.
\end{abstract}

Keywords: Development, Media, Learning, Education, Economics.

Copyright (c) 2021 Febby Febriantika Noer Fisabilillah, Norida Canda Sakti

Corresponding author:

Email : febbyfebrie80@gmail.com

DOI : https://doi.org/10.31004/edukatif.v3i4.562

ISSN 2656-8063 (Media Cetak)

ISSN 2656-8071 (Media Online)

Edukatif : Jurnal Ilmu Pendidikan Vol 3 No 4 Tahun 2021 p-ISSN 2656-8063 e-ISSN 2656-8071 
1272 Pengembangan Video Animasi Sebagai Upaya Peningkatan Minat Belajar Peserta Didik Materi Perpajakan di Sekolah Menengah Atas - Febby Febriantika Noer Fisabilillah, Norida Canda Sakti DOI: https://doi.org/10.31004/edukatif.v3i4.562

\section{PENDAHULUAN}

Kegiatan belajar mengajar saat ini dilakukan dengan menggunakan daring, yang diakibatkan oleh kebijakan pemerintah akibat pandemi covid 19. Sehingga berdampak pada kegiatan pembelajaran yang mengalami beberapa kendala dalam proses pembelajaran baik dari penyampaian materi yang diajarkan, tugas yang diberikan, dan keaktifan atau turunnya semangat belajar peserta didik karena pembelajaran yang tidak dilakukan secara langsung disekolah. Sehingga dengan berbagai kendala yang ada membawa pengaruh pada turunnya hasil belajar yang disebabkan oleh rendahnya minat belajar peserta didik.

Oleh karenanya, dengan adanya perkembangan dalam bidang teknologi informasi saat ini. Dengan berbagai perangkatat lunak yang bisa digunakan secara gratis maupun berbayar sesuai kebutuhan dan kualitas yang diinginkan membuat kita atau seorang guru bisa lebih kreatif lagi untuk mengembangkan media pembelajaran yang menarik dengan menggunakan perangkat yang sudah ada. Karena Menurut Riyana (2007:2) media video pembelajaran berfungsi untuk membantu pemahaman terhadap materi yang dipelajari berbanti dengan adanya audio, gambar, dan animasi yang dikombinasikan.

Hal itu merujuk pada penelitian (Rachmavita, 2020) "In increasing students 'motivation to learn, it is necessary to have learning media that marks students' interest in learning in the subject or material to be studied". Disamping itu ada juga penjelasan bahwa "In a traditional classroom, learning activities based on a web environment can be carried out to achieve the needs of students who are needed in a class where learning is carried out in a modern way" (Teoh \& Neo, 2007). Hal itu juga dikuatkan dengan adanya pendapat "Animations and designs that can be accessed digitally via cell phones can increase the interest of students" yang artinya animasi dan desain yang dapat diakses secara digital melalui ponsel dapat meningkatkan minat peserta didik.(Bello-bravo et al., 2018).

Pengembangan video animasi sendiri bertujuan dalam peningkatan minat belajar peserta didik yang didukung oleh penelitian terdahulu yang sudah dilakukan. Diantaranya menjelaskan bahwa alternatif pembelajaran yang menggunakan video animasi dapat dikembangkan dengan materi yang lain (Wuryanti \& Kartowagiran, 2016). Selain itu, peserta didik berbantu video animasi dengan penerapan Blenden Learning menjadi lebih aktif dalam segala hal saat belajar matematika daripada peserta didik yang beajar secara tradisional (Sudiarta \& Sadra, 2016)

Penelitian lain juga menjelaskan bahwa "By using 3D video animation, students were motivated and interested; they showed more comprehension and were able to discover new things." (Francis, 2016). Other research also shows "that Learning is carried out properly to increase students' interest in learning through various learning activities with the use of iSpring-based interactive mathematics multimedia" (Anwar et al., 2019).

Terdapat pula penelitian yang mengungkapkan bahwa hasil dan motivasi belajar peserta didik yang menggunakan media animasi lebih tinggi dibadingdang yang diterapkan media pembelajaran powerpoint (Sukiyasa \& Sukoco, 2013). Hal itu juga terjadi pada peserta didik yang kegiatan pembelajaran diterapkan video motion graphic dengan model pembelajaran problem based learning lebih tinggi dibandingkan tanpa diterapkan media video motion graphic (Wardhani \& Muchsini, 2018). Adapula media pembelajaran yang mebantu guru dalam penyampaian materi serta pemahaman peserta didik yang dijadikan pilihan dalam mata pelajaran IPS adalah video animasi Hands Move (Permatasari et al., 2019). Selain itu, penerapan media film animasi yang digunakan sebagai media pembelajaran juga sudah termasuk dalam kriteria baik yang layak digunakan dan sudah dinilai oleh ahli media (Hasanah \& Nulhakim, 2015).

Dari beberapa penelitian sebelumnya terkait dengan penerapan media pembelajaran video animasi, belum ada yang diterapkan pada pelajaran ekonomi dengan materi perpajakan, dan juga digunakan pada waktu pembelajaran jarak jauh yang lebih membutuhkan media pembelajaran menarik sekaligus bisa dijadikan sebagai media pembelajaran mandiri untuk pengulangan materi yang belum dipahami. Sehingga 
1273 Pengembangan Video Animasi Sebagai Upaya Peningkatan Minat Belajar Peserta Didik Materi Perpajakan di Sekolah Menengah Atas - Febby Febriantika Noer Fisabilillah, Norida Canda Sakti DOI: https://doi.org/10.31004/edukatif.v3i4.562

peneliti memilih metode pengembangan Reearch and Development (R\&D) yang membuat adanya sebuah produk pembelajaran terkait analisis akan kebutuhan peserta didik selama pembelajaran yang dilakukan dengan daring.

Hal ini berdasarkan masalah yang telah diamati melalui pengalaman praktik mengajar lapangan (PLP) yang dilakukan peneliti di SMAN 14 Surabaya, dan membuktikan adanya berbagai kendala dari sisi peserta didik, dimana setiap kali kelas yang dilakukan secara online menggunakan berbagai media yang ada seperti zoom, meet, maupun google classrom, tingkat kehadiran peserta didik yang rendah dibuktikan dengan adanya hasil presensi online pada moodle yang digunakan sebagai wadah media pembelajaran di SMAN 14 dikala pandemi saat ini. Berikut data tabel prsensi kehadiran peserta didik di kelas XI IPS 4 dengan total peserta didik 36:

Tabel 1

Presensi dan pengumpulan tugas

\begin{tabular}{|l|l|l|l|l|l|l|}
\hline \multirow{2}{*}{ Keterangan } & \multicolumn{7}{|c|}{ Pertemuan } \\
\cline { 2 - 8 } & $\mathbf{1}$ & $\mathbf{2}$ & $\mathbf{3}$ & $\mathbf{4}$ & $\mathbf{5}$ & $\mathbf{6}$ \\
\hline Kehadiran & 26 & 24 & 23 & 24 & 22 & 18 \\
\hline $\begin{array}{l}\text { Pengumpulan } \\
\text { Tugas }\end{array}$ & 6 & $\begin{array}{l}\text { Tidak ada } \\
\text { tugas }\end{array}$ & 9 & 4 & $\begin{array}{l}\text { Tidak ada } \\
\text { tugas }\end{array}$ & 5 \\
\hline
\end{tabular}

Sumber: Data diolah peneliti

Hasil data diatas bersumber pada moodle dari hasil observasi peneliti yang dilakukan saat PLP yang menunjukkan tingkat kehadiran peserta didik pada tiap pertemuan mengalami penurunan. Selain itu, kehadiran peserta didik yang dilihat dari moodle tidak sama dengan jumlah peserta didik yang benar-benar ikut dalam kelas online melalui media google meet, itu disebabkan absensi peserta didik yang dilakukan secara mandiri di moodle dari pihak sekolah. Sedangkan peserta didik yang benar-benar mengikuti kelas online juga memiliki tingkat keaktifan yang rendah, dilihat dari jarangnya peserta didik yang on cam ataupun on mic saat kelas, jarang bertanya terhadap materi yang dijelaskan, dan butuh waktu untuk menyuruh peserta didik menjawab pertanyaan atau rangsangan yang sudah diberikan terkait materi yang diajarkan. Apalagi pembelajaran ekonomi untuk kelas XI SMAN 14 Surabaya yang susah untuk dipahami peserta didik karena banyaknya materi yang diajarkan dilihat dari waktu pengajaran yang menghabiskan beberapa pertemuan karena keterbatasan jam pembelajaran online. Apalagi dengan pembelajaran yang saat ini dilakukan secara daring membuat keaktifan peserta didik dan keikutsertannya dalam mengikuti kelas sangat rendah, dan jumlah peserta didik yang mengumpulkan tugas juga tidak ada 50\% dari jumlah peserta didik tiap kelas, sehingga guru sulit untuk mengetahui sejauh mana pemahaman peserta didik karena kurang efektifnya media evaluasi berupa pertanyaan maupun tugas soal yang diberikan. Dan berpengaruh pada hasil belajar karena minat belajar yang kurang.

Selain itu, menurut hasil observasi dan wawancara kepada guru ekonomi XI IPS 4 di SMAN 14 Surabaya mengungkapkan bahwa peserta didik memiliki minat belajar yang terbilang rendah karena beberapa faktor yang mempengaruhi. Salah satunya disebabkan karena minat belajar yang tinggi dibutuhkan adanya rangsangan, stimulus, atau dorongan dan ketertarikan peserta didik terhadap materi pembelajaran. Karena pada dasarnya minat belajar peserta didik terhadap proses pembelajaran tidak bisa muncul dengan sendirinya, tetapi terdapat beberapa faktor lain. Diantaranya bisa disebabkan oleh bahan pembelajaran yang menarik, adanya hubungan antara pembelajaran dan kehidupan nyata disekitar peserta didik, guru yang menyenangkan, dan kesempatan keaktifan peserta didik saat kegiatan pembelajaran. Sehingga diperlukan adanya media video sebagai bantuan pemberian rangsangan, pemahaman materi ataupun media evaluasi.

Maka dari itu, video animasi perlu diterapkan sebagai upaya peningkatan minat belajar peserta didik kelas XI pada mata pelajaran ekonomi materi perpajakan agar tidak semakin berpengaruh pada turunnya hasil belajar atau ketidakefesienan pembelajaran saat ini yang dilakukan secara daring. Video animasi sendiri 
1274 Pengembangan Video Animasi Sebagai Upaya Peningkatan Minat Belajar Peserta Didik Materi Perpajakan di Sekolah Menengah Atas - Febby Febriantika Noer Fisabilillah, Norida Canda Sakti DOI: https://doi.org/10.31004/edukatif.v3i4.562

berisikan materi pembelajaran perpajakan dengan durasi 15 menit mulai dri pendahuluan yang berisikan KD, indikator, tujuan dan manfaat mempelajari materi, serta stimulus/rangsangan berupa kuis, lalu dilanjut dengan penjelasan materi yang menarik dengan adanya animasi serta audio, lalu ditutup dengan soal evaluasi 5 pilihan ganda dan 3 soal analisi beserta penjelasan jawabnnya dan ditutup dengan kesimpulaan serta motivasi. Dimana nantinya peserta didik dapat menggunan video animasi untuk dijadikan media pembelajaran mandiri untuk mengulang materi di luar jam pembelajaran.

Oleh karenanya berdasarkan latar belakang permasalahan yang dipaparkan, serta perbedaan penelitian ini dengan penetian sebelumnya yaitu penerapan media pembelajaran saat ini yang dilakukan secara daring sehingga peserta didik membutuhkan media pembelajaran yang menarik minat untuk belajar, maka dari itu ada penelitian ini yang berjudul "Pengembangan Video Animasi Sebagai Upaya Peningkatan Minat Belajar Peserta Didik Materi Perpajakan Kelas XI SMAN 14 Surabaya yang berbeda dengan penelitian sebelumnya karena diterapkan untuk pertamakalinya dalam kondisi pembelajaran secara daring, sehingga penting untuk diterapkan karena bantuan media pembelejaran sangat dibutuhkan peserta didik untuk meningkatkan minat belajaranya karena banyaknya faktor masalah kesulitan belajar atau pemahaman materinya yang akan berpengaruh pada hasil belajar.

\section{METODE PENELITIAN}

Jenis peneltian ini menggunakan metode Research and Development (R\&D). Menurut (Sukamadinata \& Nana, 2009) menjelaskan bahwa "penelitian dan pengembangan adalah suatu proses atau langkah-langkah untuk mengembangkan suatu produk baru atau menyempurnakan produk yang telah ada dan dapat dipertanggungjawabkan".

Prosedur pengembangan media pengembangan menggunakan media video animasi ini memiliki 4 tahapan sesuai dengan model yang dikembangkan oleh (Thiagarajani 1974: 6-9) yakni Pendefinisian (Define), Perencanaan (Design), Pengembangan (Develop), dan Penyebaran (Disseminate).

Penelitian yang dilakukan ini menggunakan subjek penelitian kelas XI IPS 4 SMAN 14 Surabaya. Dengan teknik pengumpulan data wawancara kepada guru mata pelajaaran ekonomi di SMAN 14 Surabaya, observasi yang dilakukan saat PLP untuk melihat kendala atau masalah saat proses pembelajaran yang dilakukan secara daring, analisis dengan menggunakan skala likert untuk lembar telaah dan validasi ahli, dan analisis menggunakan skala guttman untuk angket respon peserta didik. Analisis data dari hasil validasi dan angket dilakukan dengan teknik dibawah ini:

Nilai $=$ Nilai yang diperoleh $\mathrm{x} 100$

Kesimpulan dari hasil analisis yang didapat mengenai pengembangan media video animasi dilihat berdasarkan kriteria dibawah ini:

Tabel 2

Kriteria validitas

\begin{tabular}{|l|l|}
\hline Kriteria validitas & Tingkat Validitas \\
\hline $81-100$ & Sangat layak \\
\hline $61-80$ & Layak \\
\hline $41-60$ & Cukup layak \\
\hline $21-40$ & Tidak layak \\
\hline $0-20$ & Sangat tidak layak \\
\hline
\end{tabular}

Sumber: Riduwan (2015:17)

Sehingga media pembelajaran video animasi dinyatakan layak digunakan apabila nilai yang diperoleh $\geq$ 61 dengan kriteria layak atau sangat layak yang diperoleh dari vaalidator ahli dan peserta didik. 
1275 Pengembangan Video Animasi Sebagai Upaya Peningkatan Minat Belajar Peserta Didik Materi Perpajakan di Sekolah Menengah Atas - Febby Febriantika Noer Fisabilillah, Norida Canda Sakti

DOI: https://doi.org/10.31004/edukatif.v3i4.562

\section{HASIL DAN PEMBAHASAN}

Hasil pengembangan video animasi yang sudah diterapkan peneliti pada kelas XI SMAN 4 Surabaya sebagai upaya peningkatan minat belajar peserta didik materi perpajakan menghasilkan data setiap tahapan yakni:

\section{Tahap pendefinisian (Define)}

Tahap pendefinisian mendefinisikan kebutuhan dalam pembuatan produk media pembelajaran video animasi melalui beberapa tahapan pendefinisian yaitu: a) Analisis awal yang membandingkan kelas dan materi pembelajaran yang akan diterapkan media pembelajaran video animasi karena adanya indikator minat belajar yang rendah sehingga ditentukan bahwa subjek penelitian pada kelas XI IPS 4, b) Analisis peserta didik dengan analisis sebagai berikut: Peserta didik kelas XI IPS 4 SMAN 14 Surabaya berjumlah 36 peserta didik, Peserta didik kesulitan dalam pemahaman materi karena proses pembelajaran yang dilakukan secara daring, Peserta didik lebih suka menerima informasi dengan penyajian materi yang menarik, c) Analisis konsep yang menganalisis dan menentukan materi yang akan digunakan dalam proses penerapan media pembelajaran dimana didalamnya terdapat kompetensi dasar, indikator, tujuan pembelajaran, sehingga materi yang disajikan melalui media video animasi sesuai dengan KD 3.7 yakni menganalisis perpajakan dalam pembangunan ekonomi dengan indikator pencapaian kompetensi seperti pada gambar dibawah ini:

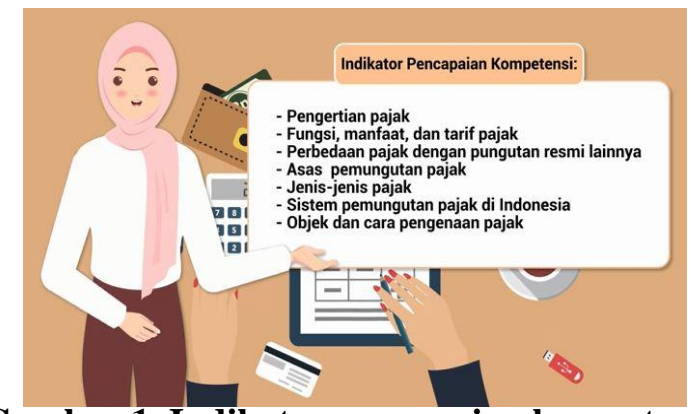

\section{Gambar 1. Indikator pencapaian kompetensi}

Dengan adanya indikator yang jelas dan ditampilkan diawal pembelajaran dalam video animasi, difungsikan agar peserta didik mengetahui materi apa saja yang akaan dipelajari melalui video animasi tersebut, d) Analisis tugas yang menyajikan kelengkapan materi berdasarkan indikator yang ada dengan memberikan stimulus atau rangsangan berupa soal agar menarik minat peserta didik dalam selama proses pembelajaran.

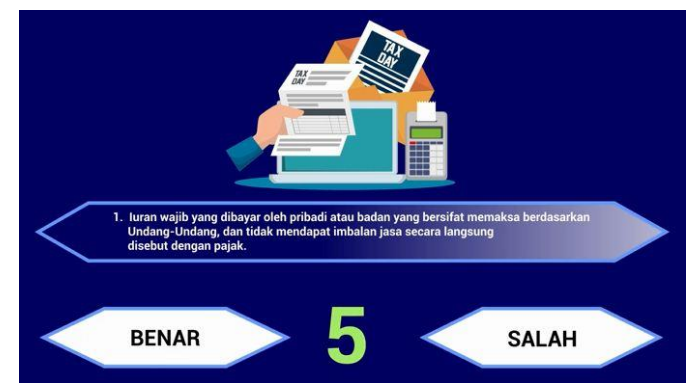

\section{Gambar 2. Stimulus/rangsangan awal pembelajaran}

Stimulus/rangsangan yang diberikan diawal pembelajaran berupa kuis "Benar" atau "Salah" dengan diberi waktu 5 detik sebelum jawaban yang benar akan menyala. Hal itu digunakan untuk mengetahui sejauh mana pengetahuan peserta didik terait materi perpajakan yang akan dipelajari.

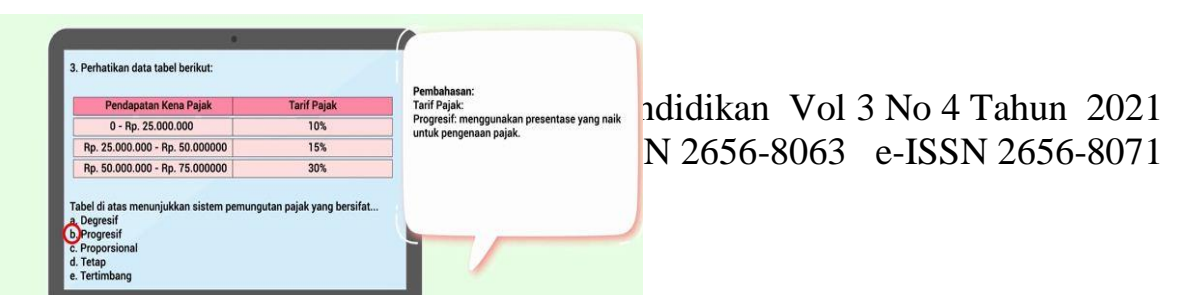




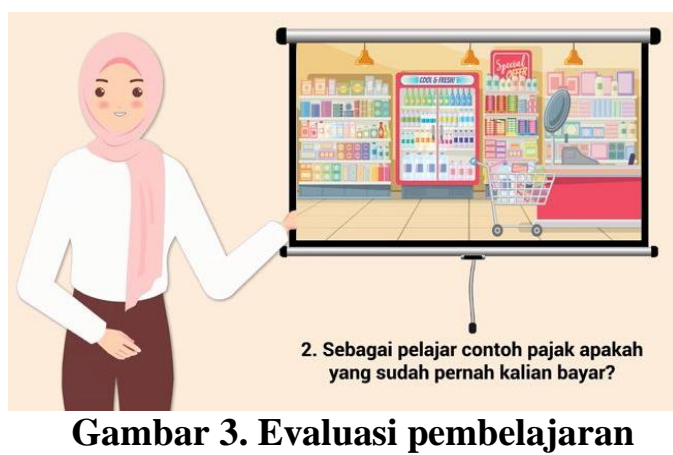

Diakhir pembelajaran dalam video animasi diberikan 5 pertanyaan pilihan ganda dengan diberikan penjelasan setelah beberapa waktu dan juga 3 soal analisis. Hal itu bertujuan untuk mengetahui pemahaman materi peserta didik setelah penerapan media video animasi, e) Analisis perumusan tujuan pemelajaran yang menganalisi fungsi dan peran pajak dalam pemangunan ekonomi.

2. Tahap Perencanaan (Design)

Perencanaan pengembangan media pembelajaran video animasi dilakukan dengan2 tahapan yaitu pemilihan media dan formatnya.

\section{Tahap pengembangan (Develop)}

Pengembangan media pembelajaran video animasi dilakukan melalui 2 tahapan yaitu: a) Telaah dan validasi ahli yang dilakukan oleh peneliti guna mendapatkan penilaian dari para ahli berupa saran atau masukan untuk perbaikan media pembelajaran video animasi yang divalidasi oleh para validator. Sehingga diperoleh data hasil telaah terhadap kelayakan, kepraktisan, dan keefktifan materi serta media pembelajaran video animasi yang ditelaah oleh dosen ahli dalam bidangnya yaitu Bapak Dr. Norida Canda Sakti, M.Si yaitu dosen Pendidikan Ekonomi di Universitas Negeri Surabaya dan Dr.Fajar Arianto, M.Pd yaitu dosen Teknologi Pendidikan di Universitas Negeri Surabaya. Komentar para ahli terhadap pengembangan media pembelajaran video animasi adalah sebagai berikut:

Tabel 3

Hasil telaah validator ahli

\begin{tabular}{|l|l|l|}
\hline No. & Nama & Komentar dan Saran Perbaikan \\
\hline 1 & Dr. Norida Canda Sakti, M.Si & - Materi pembelajaran perpajakan layak dan dapat \\
& & dipergunakan untuk menambah bahan ajar dalam mata \\
& & pelajaran ekonomi di sekolah \\
& & - Media pembelajaran sangat praktis dan dapat digunakan \\
& & sebagai media pembelajara ekonomi di sekolah \\
& & - Media pembelajaran sangat efektif serta dapat \\
& & dipergunakan sebagai media pembelajaran ekonomi di \\
& & sekolah \\
\hline 2 & Dr.Fajar Arianto, M.Pd & Media pembelajaran video animasi sudah bagus dan layak \\
& & sehingga bisa lansung diterapkan untuk pembelajaran \\
\hline
\end{tabular}

Sumber: Data diolah peneliti

Dari saran dan masukan tersebut tidak ada revisi untuk produk video animasi yang akan dikembangkan, sehingga video animasi bisa lagsung diujicobakan pada peserta didik. Lalu selanjutnya data hasil validasi validator ahli dalam pemberian nilai pada lembar validasi menggunakan pilihan skala likert yang akan dianalisis dengan teknik analisis data yang dipilih. 
1277 Pengembangan Video Animasi Sebagai Upaya Peningkatan Minat Belajar Peserta Didik Materi Perpajakan di Sekolah Menengah Atas - Febby Febriantika Noer Fisabilillah, Norida Canda Sakti DOI: https://doi.org/10.31004/edukatif.v3i4.562

Tabel 4

Hasil validasi validator ahli

\begin{tabular}{|l|c|l|}
\hline \multicolumn{1}{|c|}{$\begin{array}{c}\text { Aspek } \\
\text { Validasi }\end{array}$} & $\begin{array}{c}\text { Hasil } \\
\text { Keseluruhan }\end{array}$ & Kriteria \\
\hline Materi & $89,5 \%$ & Sangat Layak \\
\hline Media & $97 \%$ & Sangat Layak \\
\hline Kefektifan & $92 \%$ & Sangat Layak \\
\hline Kepraktisan & $94 \%$ & Sangat Layak \\
\hline
\end{tabular}

Sumber: Data diolah peneliti

Dan berdasarkan data yang telah diperoleh dari validator ahli, validasi materi mendapat presentas sebesar 89,5\% dengan kategori sangat layak, validasi kelayakan mendapat presentase sebesar 97\% dengan kategori sangat layak, validasi kepraktisan mendapat presentase sebesar 94\% dengan kategori sangat layak, serta validasi keefektifan media mendapatkan presentase sebesar 92\% dengan kategori sangat layak. selanjutnya yakni b) Uji coba lapangan dimana produk pengembangan video animasi akan dilakukan atau diimplementasikan terhadap peserta didik kelas XI sejumlah 36 yang dijadikan sebagai subjek penelitian dengan mengisi angket yang berisikan 4 indikator dengan 16 pernyataan menggunakan skala guttman dengan perolehan skor 1 untuk jawaban "Ya" dan 0 untuk jawaban "Tidak". Berikutt tabel hasil angket peserta didik:

Tabel 5

Hasil angket respon peserta didik

\begin{tabular}{|l|l|l|}
\hline Indikator & Presentase & Kriteria \\
\hline $\begin{array}{l}\text { Perasaan } \\
\text { senang }\end{array}$ & $90,3 \%$ & Sangat Layak \\
\hline Keterlibatan & $88,3 \%$ & Sangat Layak \\
\hline Ketertarikan & $87 \%$ & Sangat Layak \\
\hline Perhatian & $86 \%$ & Sangat Layak \\
\hline $\begin{array}{l}\text { Rata-rata } \\
\text { Keseluruhan }\end{array}$ & $87,9 \%$ & Sangat Layak \\
\hline
\end{tabular}

Sumber: Data diolah peneliti

Berdasarkan data yang diperoleh hasil dari angket respon peserta didik diperoleh presentase sebesar 87,9\% yang berarti bahwa media pembelajaran video animasi yang dikembangkan terhadap peserta didik memiliki kriteria sangat layak.

4. Tahap penyebaran (Disseminate)

Dilakukan secara terbatas dengan mempromosikan produk akhir video animasi terhadap guru mata pelajaran ekonomi di SMAN 14 Surabaya.

Pembahasan dari hasil penelitian pengembangan media video animasi sebagai upaya peningkatan minat belajar peserta didik materi perpajakan kelas XI SMAN 14 Surabaya.

1. Kelayakan video animasi.

Kelayakan video animasi dalam meningkatkan minat belajar peserta didik materi perpajakan kelas XI SMAN 14 Surabaya dinilai layak untuk dikembangkan sebagai bentuk upaya peningkatan minat belajar peserta didik pada materi perpajakan yang diuji cobakan pada peserta didik kelas XI SMAN 14 Surabaya ini dapat dilihat dari hasil data validasi tentang kelayakan penggunaan media video animasi ini. Oleh karenanya 
1278 Pengembangan Video Animasi Sebagai Upaya Peningkatan Minat Belajar Peserta Didik Materi Perpajakan di Sekolah Menengah Atas - Febby Febriantika Noer Fisabilillah, Norida Canda Sakti DOI: https://doi.org/10.31004/edukatif.v3i4.562

validasi yang dilakukan mencakup validasi media dan validasi materi yang sudah divalidasi oleh validator ahli dibidangnya.

Validasi media yang dilakukan mencakup beberapa aspek yakni kualitas media, penggunaan bahasa, relevansi, kesesuaian video dengan tujuan pembelajaran yang berpusat pada peserta didik, dan penyajian media. Dimana rata-rata keseluruhan aspek mendapat presentase sebesar 97\% dengan kategori sangat layak. Sehingga media pembelajaran video animasi bisa langsung diterapkan dalam kegiatan pembelajaran.

Berikutnya validasi materi yang juga memiliki beberapa aspek penilaian didalamnya yaitu mencakup kualitas materi, kemanfaatan materi, proses pembelajaran (mulai dari pendahuluan, isi dan penutup), serta pemberian soal. Hasil dari validasi materi, memperoleh rata-rata presentase sebesar $89,5 \%$ yang berarti sangat layak. Materi perpajakan yang digunakan dan diterapkan dalam media pembelajaran video animaasi dapat diaplikasikan dengan baik di sekolah.

Dari data tersebut dapat disimpulkan bahwa media pembelajaran video animasi materi perpajakan sangat layak untuk digunakan sebagai upaya peningkatan minat belajar peserta didik kelas XI di SMAN 14 Surabaya apalagi dimasa paandemi yang mengharuskan kegiatan pembelajaran dilakukan secara daring. Hal ini juga didukung oleh penelitian sebelumnya (Amrulloh et al., 2013) bahwa media pembelajaran multimedia interaktif dinilai layak dalam segi materi dan media secara teoritis. Serta sesuai dengan penelitian (Sari et al., 2017) yang juga mengungkapkan bahwa media pembelajaran berbasis video animasi layak digunakan sebagai media pembelajaran setelah dilakukan beberapa tahapan analisis dan uji validasi.

2. Keefektifan video animasi.

Keefektifan video animasi dalam meningkatkan minat belajar peserta didik materi perpajakan kelas XI SMAN 14 Surabaya dijadikan sebagai salah satu upaya peningkatan minat belajar materi perpajakan kelas XI SMAN 14 Surabaya dapat dilihat dari hasil data validasi efektivitas oleh validator ahli dibidangnya yang meliputi beberapa aspek penilaian diantaranya yakni minat dan motivasi, fungsi media pembelajaran, dan reabilitas. Berdasarkan data yang diperoleh dari validasi efektifitas diperoleh presentase sebesar $92 \%$ dengan katergori sangat layak. Sehingga dapat disimpulkan bahwa media pembelajaran video animasi efektif untuk dipergunakan sebagai media pembelajaran ekonomi di sekolah.

Hal itu juga sesua dengan penelitian sebelumnya (Widiyasanti \& Ayriza, 2018) yang mengungkapkan bahwa pembelajaran video animasi lebih efektif dalam meningkatkan karakter dan motivasi belajar peserta didik dibandingkan dengan media gambar. Serta dapat dijadikan sebagai media evaluasi pembelajaran untuk hasil belajar (Wardoyo \& Faqih Ma'arif, 2015)

3. Kepraktisan penggunaan video animasi.

Kepraktisan penggunaan video animasi dalam meningkatkan minat belajar peserta didik materi perpajakan kelas XI SMAN 14 Surabaya yang diterapkan sebagai media pembelajaran juga harus mencakup unsur kepraktisan, sehingga untuk mengukur tingkat kepratisan penerapan media pembelajaran video animasi dinilai dari aspek manfaat dan penggunaannya. Validasi ini juga dinilai oleh validator ahli dibidangnya. Hasil validasi yang sudah dilakukan menghasilkan presentase 94\% untuk masing-masing aspek sehingga menghasilkan kategori sangat layak.

Berdasarkan data tersebut dapat disimpulkan bahwa media pembelajaran video animasi yang diterapkan sebagai upaya dalam meningkatkan minat belajar peserta didik materi perpajakan kelas XI sangat praktis dan dapat digunakan sebagai media pembelajaran di sekolah. Hal itu juga sesuai dengan penelitian (Mashuri \& Budiyono, 2020) yang juga membuktikan bahwa media pembelajaran video animsi dinilai praktis untuk diterapkan ke peserta didik berdasarkan konversi tingkat pencapaiannya.

4. Respon peserta didik terhadap penerapan video animasi

Respon peserta didik dengan adanya penerapan video animasi dalam meningkatkan minat belajar peserta didik materi perpajakan kelas XI SMAN 14 Surabaya diperoleh dari hasil uji coba lapangan kepada 
1279 Pengembangan Video Animasi Sebagai Upaya Peningkatan Minat Belajar Peserta Didik Materi Perpajakan di Sekolah Menengah Atas - Febby Febriantika Noer Fisabilillah, Norida Canda Sakti DOI: https://doi.org/10.31004/edukatif.v3i4.562

kelas XI IPS 4 SMAN 14 Surabaya yang berjumlah 36 peserta didik. Respon peserta didik sendiri dilihat dari penerapan media pembelajaran video animasi dengan adanya angket yang telah dibagikan dan diisi oleh peserta didik setelah dilakukannya proses kegiatan pembelajaran dengan menggunakan media video animasi. Dalam angket yang dibagikan terdapat beberapa variabel penilaian sesuai dengan indikator yang diukur yakni minat belajar peserta didik. Sehingga dalam penerapan media pembelajaran video animasi dalam kegiatan pembelajaran, peneliti mengukur respon peserta didik dengan menggunakan 4 aspek yakni perasaan senang, keterlibatan peserta didik, ketertarikan peserta didik, dan perhatian peserta didik.

Dari hasil angket peserta didik yang mengunakan skala guttman dilakukan analisis oleh peneliti yang menghasilkan data presetase rata-rata masing-masing aspek penilaian. Untuk aspek perasaan senang peserta didik diperoleh presentase rata-rata 90,3\% yang berarti sangat layak, aspek keterlibatan peserta didik diperoleh presentase sebesar $88,3 \%$ dengan kategori sangat layak, ketertarikan peserta didik diperoleh presentase sebesar $87 \%$ dengan kategori sangat layak, dan perhatian peserta didik diperoleh pesentasi rata-rata sebesar $86 \%$ dengan kategori sangat layak. Sehingga hasil keseluruhan dari angket respon peserta didik diperoleh data presentase sebesar $87,9 \%$ yang berarti bahwa media pembelajaran video animasi yang dikembangkan memilikikriteria sangat layak dari peserta didik.

Berdasarkan data tersebut disimpulkan bahwa penerapan media pembelajaran media video animasi sebagai dalam meningkatkan minat belajar peserta didik materi perpajakan kelas XI IPS 4 SMAN 14 Surabaya mendapatkan respon sangat layak oleh peserta didik dalam penerapannya. Hal itu juga merujuk pada penelitian (Mashuri \& Budiyono, 2020) sebelumnya bahwa peserta didik terlihat antusias saat pembelajaran karena tumbuhnya minat belajar saat diterapkannya media pembelajaran video animasi. Dan penelitian (Susanti, 2019) yang juga mengungkapkan bahwa media gambar dan audiovisual membantu guru saat proses pembelajaran untuk membuat peserta didik lebih aktif dan kreatif.

\section{Pengembangan video animasi}

Pengembangan video animasi dalam meningkatkan minat belajar peserta didik materi perpajakan kelas

XI SMAN 14 Surabaya diketahui setelah menerapkan tahapan tersebut sehingga terdapat perbedaan atau peningkatan dilihat dari masalah yang melatarbelakangi di aplikasikannya media pembelajaran video animasi. Peningkatan itu dilihat saat pembelajaran berlangsung dimana peserta didik yang sebelumnya malas mengikuti kelas menjadi hadir mengikuti kelas, lalu perhatian peserta didik yang rendah karena dilakukan secara daring menjadi lebih aktif dengan media pembelajaran video animasi dibantu dengan adanya stimulus atau rangsangan pemberian kuis dan soal. Selain itu peserta didik menjadi lebih bersemangat untuk belajar ekonomi khususnya pada materi perpajakan karena adanya minat belajar yang didorong oleh penggunaan media belajar yang menarik yakni video animasi. Dan mengakui tumbuhnya kesadaran belajar karena dapat memahami isi materi yang dianggap sulit tetapi menjadi lebih mudah dipahami dengan bantuan media pembelajaran video animasi. Selain itu peserta didik mendapatkan keuntungan dalam penggunaan media pembelajaran video animasi karena dapat dipergunakan ketika pembelajaran yang dilakukan di kelas maupun pengulangan di rumah secara mandiri jika membutuhkan pengulangan materi yang kurang jelas karena sudah di lengkapi dengan materi dan audio yang jelas.

Hal ini juga dibuktikan dengan keberhasilan indikator minat belajar yang diujikan pada angket respon peserta didik setelah penerapan media pembelajaran video animasi yang didalamnya terdapat perasaan senang, keterlibatan, ketertarikan, dan perhatian peserta didik. Sehingga media pembelajaran video animasi dinilai dapat dijadikan sebagai bentuk upaya dalam meningkatkan minat belajar dilihat dari peserta didik yang memberikan respon dengan presentase sebesar $87,9 \%$ yang berarti sangat layak. Oleh karenanya dapat ditarik kesimpulan bahwa video animasi yang dijadikan sebagai media pembelajaran dapat dipergunakan untuk mendorong atau meningkatkan minat belajar peserta didik materi perpajakan apalagi saat pembelajaran jarak jauh yang saat ini diterapkan dan membutuhkan media pembelajaran yang tepat tetapi tetap menarik minat peserta didik untuk belajar. 
Hal ini merujuk pada penelitian sebelumnya (Rochimah, 2019) bahwa media pembelajaran video anmasi berhasil meningkatkan minat belajar peserta didik. Dan sesuai dengan pendapat Hamlik (1986) yang menjelaskan bahwa untuk membangkitkan minat, keinginan, motivasi, serta rangsangan, bahkan untuk membawa pengaruh psikologus peserta didik dibutuhkan penerapan media pembelajaran. Sehingga sesuai juga dengan penelitian (Wuryanti \& Kartowagiran, 2016) bahwa media video animasi layak dan efektif dalam meningkatkan motivasi belajar peserta didik.

Sehingga pengembangan media video animasi yang diujicobakan secara berbeda dengan penelitian sebelumnya karena pembelajaran yang dilakukan secara daring saat ini menunjukkan hasil yang sama, bahwa pengembangan video animasi sangat layak dan efektif diterapkan apalagi dengan kondisi saat ini dimana bantuan media pembelajaran yang menarik sangat dibutuhkan untuk tetap mempertahankan dan meningkatkan minat belajar peserta didik. Oeh karenanya, diperluukan pengaplikasian media video animasi ini pada mata pelajaran lain, bukan hanya ekonomi dan dengan materi yang dibutuhkan oleh peserta didik atau yang dianggap sulit, serta dapat disebarluaskan secara lebih luas. Selain itu, pada penelitian ini belum dikombinasikan untuk model atau pendekatan belajar lain sehingga untuk kedepannya bisa dikembangkan dengan model atau metode pembelajaran yang dibutuhkan

\section{KESIMPULAN}

Berdasarkan hasil penilitian pengembangan media pembelajaran video animasi sebagai upaya meningkatkan minat belajar peserta didik materi perpajakan kelas XI SMAN 14 Surabaya yang sudah dilakukan dengan menggunakan metode Research and Developmen (R\&D). Menghasilkan data untuk mengetahui kelayakan, efektifitas, kepraktisan, sekaligus respon peserta didik dan pengembangan media pembelajaran video animasi. Dimana media pembelajaran video animasi dinilai sangat layak dengan perolehan validasi kelayakan $97 \%$ untuk media dan $89,5 \%$ untuk materi, keefektifan $92 \%$, dan kepraktisan 94\%. Selain itu, peserta didik memberikan respon bahwa adanya penerapan media pembelajaran video animasi dalam meningkatkan minat belajar materi perpajakan memperoleh presentase $87,9 \%$ yang berarti media pembelajaran sangat layak diterapkan bagi peserta didik apalagi dengan kondisi pembelajaran daring saat ini. Oleh karenanya dapat disimpulkan bahwa pengembangan video animasi bagi peserta didik untuk meningkatkan minat belajarnya pada materi perpajakan dapat dilihat dari presentase yang diberikan peserta didik dengan presentase respon sebesar $87,9 \%$ yang berarti sangat baik untuk dijadikan sebagai upaya peningkatan minat belajar peserta didik untuk mengatasi permasalahan atau kesulitan belajar peserta didik dengan pembelajaran yang dilakukan secara daring saat ini sehingga adanya pengembangan media video animasi yang digunakan dalam proses pembelajaran berhasil untuk menarik minat belajar peserta didik dalam meningkatkan perasaan senang, keterlibatan, ketertarikan, dan perhatian peserta didik.

\section{DAFTAR PUSTAKA}

Amrulloh, R., Yuliani, \& Isnawati. (2013). Kelayakan Teoritis Media Pembelajaran Multimedia The Feasibility Theoretical Of Learning Media Of Interactive Multimedia In The Topic Of Mutation For Senior High School Rizqi Amrulloh, dkk : Kelayakan Teoretis Media Rizqi Amrulloh, dkk : Kelayakan Teore. Berkala Ilmiah Pendidikan Biologi, 2, 134-136.

Anwar, M. S., Choirudin, Ningsih, E. F., Dewi, T., \& Maseleno, A. (2019). Developing an Interactive Mathematics Multimedia Learning Based on Ispring Presenter in Increasing Students' Interest in Learning Mathematics. Jurnal Pendidikan Matematika, 10(1), 135-150.

Bello-bravo, J., Tamò, M., Dannon, E. A., \& Robert, B. (2018). An Assessment Of Learning Gains From Educational Animated Videos Versus Traditional Extension Presentations Among Farmers In Benin. 24. https://doi.org/10.1080/02681102.2017.1298077

Francis, M. P. (2016). The Effect Of 3D Video Animation On BT2 I Students' Motivation, Comprehension 
1281 Pengembangan Video Animasi Sebagai Upaya Peningkatan Minat Belajar Peserta Didik Materi Perpajakan di Sekolah Menengah Atas - Febby Febriantika Noer Fisabilillah, Norida Canda Sakti DOI: https://doi.org/10.31004/edukatif.v3i4.562

And Academic Achievement In Computer Course At A Private Vocational Institute In Mount Lebanon. International Journal of Innovation and Research in Educational Sciences, 4(5), 537-546. https://doi.org/10.13140/RG.2.2.22175.15526

Hasanah, U., \& Nulhakim, L. (2015). Pengembangan Media Pembelajaran Film Animasi Sebagai Media Pembelajaran Konsep Fotosintesis. Jurnal Penelitian Dan Pembelajaran IPA, 1(1), 91-106.

Mashuri, D. K., \& Budiyono. (2020). Pengembangan Media Pembelajaran Video Animasi Materi Volume Bangun Ruang Untuk SD Kelas V. JPGSD, 8(893-903), 1-11.

Permatasari, I. synthia, Hendracipta, N., \& Pamungkas, A. A. N. S. (2019). Pengembangan Media Pembelajaran Video Animasi Hands Move Dengan Konteks Lingkungan Pada Mapel Ips. Pendidikan Dan Pembelajaran Dasar, 6(1), 34-48.

Rachmavita, F. P. (2020). Interactive Media-Based Video Animation And Student Learning Motivation In Mathematics. Journal of Physics: Conference Series. https://doi.org/10.1088/1742-6596/1663/1/012040

Rochimah, S. (2019). Pengembangan Media Pembelajaran Berbentuk Video Animasi Pada Pokok Bahasan Keliling Dan Luas Segitiga Untuk Meningkatkan Minat Belajar Siswa Di Kelas Iv Sekolah Dasar Negeri Sumberagung Peterongan Jombang. Universitas Islam Negeri Maulana Malik Ibrahim.

Sari, S. L., Widyanto, A., \& Kamal, S. (2017). Pengembangan Media Pembelajaran Berbasisvideoanimasi Dalam Smartphone Pada Materi Sistem Kekebalan Tubuh Manusia Untuk Siswa Kelas Xi Di Sma Negeri 5 Banda Aceh. Prosiding Seminar Nasional Biotik, 476-485.

Sudiarta, I. G. P., \& Sadra, I. W. (2016). Pengaruh Model Blended Learning Berbantuan Video Animasi Terhadap Kemampuan Pemecahan Masalah Dan Pemahaman Konsep Siswa. Jurnal Pendidikan Matematika, 11, 48-58.

Sukamadinata, \& Nana, S. (2009). Metode Penelitian Pendidikan. Bandung : Remaja Rosdakarya.

Sukiyasa, K., \& Sukoco. (2013). Pengaruh Media Animasi Terhadap Hasil Belajar Dan Motivasi Belajar Siswa Materi Sistem Kelistrikan Otomotif. Jurnal Pendidikan Vokasi, 126, 126-137.

Susanti, Y. (2019). Efektivitas Model Pembelajaran Contextual Teaching Learning dan Media Audio Visual dalam Meningkatkan Motivasi, Minat dan Hasil Belajar Peserta Didik Kelas VI SDIT Taman Ilmu Kota Depok Mata Pelajaran IPA dengan Tema Ciri Khusus Hewan dan Tumbuhan. Universitas Terbuka, 53(9), 1689-1699.

Teoh, B. S., \& Neo, T. (2007). Interactive Multimedia Learning : Students' Attitudes And Learning Impact In An Animation Course. The Turkish Online Journal of Educational Technology, 6(4).

Wardhani, D. T., \& Muchsini, S. dan B. (2018). Pengaruh Model Problem Based Learning Berbantuan Video Motion Graphic Terhadap Motivasi Belajar Pada Pembelajaran Akuntansi Di Sma. Jurnal Tata Arta, $4(1), 51-61$.

Wardoyo, T. C. T., \& Faqih Ma'arif, M. E. (2015). Pengembangan Media Pembelajaran Berbasis Video Animasi Pada Mata Pelajaran Mekanika Teknik Di Smk Negeri 1 Purworejo. Jurnal Pendidikan Teknik Sipil Dan Perencanaan, 1-7.

Widiyasanti, M., \& Ayriza, Y. (2018). Pengembangan Media Video Animasi Untuk Meningkatkan Motivasi Belajar Dan Karakter Tanggung Jawab Siswa Kelas V. Jurnal Pendidikan Karakter, 1-16.

Wuryanti, U., \& Kartowagiran, B. (2016). Pengembangan Media Video Animasi Untuk Meningkatkan Motivasi Belajar Dan Karakter Kerja Keras Siswa Sekolah Dasar. Jurnal Pendidikan Karakter, 2, 232 245. 